\title{
Good Practices in the Redesign of Spaces for University Education in the Venezuelan Context of the Sucre Mission
}

\author{
Ronald M. Hernandez ${ }^{1}$, Liset Veitia Mederos ${ }^{2}$, Fidel Jesus Cabrera de la Rosa ${ }^{3}$, Aleida Suarez Ramirez ${ }^{2}$, Isabel \\ Menacho Vargas ${ }^{4}$, Henry Alarcon Diaz ${ }^{5}$, Nancy Cuenca Robles ${ }^{4} \&$ Victor Pulido Capurro ${ }^{6}$ \\ ${ }^{1}$ Universidad Católica los Ángeles de Chimbote, Perú \\ ${ }^{2}$ Universidad Central Marta Abreu de las Villas, Cuba \\ ${ }^{3}$ Universidad de Holguín, Cuba \\ ${ }^{4}$ Universidad César Vallejo, Perú \\ ${ }^{5}$ Universidad Nacional de Educación Enrique Guzmán y Valle, Perú \\ ${ }^{6}$ Universidad Privada San Juan Bautista, Perú \\ Correspondence: Ronald M. Hernandez, Universidad Católica los Ángeles de Chimbote, Perú.
}

Received: August 20, 2020

Accepted: October 15, 2020

Online Published: November 2, 2020

doi:10.5430/ijhe.v9n9p51

URL: https://doi.org/10.5430/ijhe.v9n9p51

\begin{abstract}
The objective of this article is to present the good practices in the conception of the redesign of spaces for university education in the Venezuelan context of the Sucre Mission, taking into consideration the historical context in which it takes place. The training of professionals is considered a priority for the development of nations, being desertion or abandonment a latent phenomenon that emerges as a result of dysfunctional economic scenarios or the emergence of exceptional situations. The use of the internet and mobile technology make it possible to mitigate such a situation in a challenge to maintain a quality university education; all of which demands relevant, timely and viable organizational processes.
\end{abstract}

Keywords: university education, Sucre Mission, UNESCO, distance education

\section{Introduction}

The education of the people has been a recurring theme in which not only pedagogues but also psychologists, sociologists, lawyers have studied; in pursuit of reaching higher levels of quality of life in different nations. It is taken into consideration that education and development are inextricably linked.

In this sense, in the Universal Declaration of Human Rights (1948), education occupies an important space; furthermore, it constitutes the center of UNESCO's mission. Thus, the right to education is one of the guiding principles that support the Education 2030 World Agenda, in Sustainable Development Goal number four, the purpose of guaranteeing the full enjoyment of the right to education as a catalyst for achieving sustainable development.

Education in most Latin American countries is highly affected due to the situation of poverty expressed in limitations and affectations to the way of life and, consequently, in the scarce possibilities of access to education as a basis for human development. Furthermore, rural areas are disadvantaged in meeting the needs of access with equity and real development possibilities for all.

However, in the Bolivarian Republic of Venezuela there are public policies that guarantee the access of the excluded population to educational processes, both in conventional and non-conventional programs, where the Educational Missions, devised by Hugo Rafael Chávez Frías, are reflected. It is consistent with the provisions of the Magna Carta (1999) in articles 102, 103 and 110: the right of everyone to a quality, comprehensive education, equal conditions and opportunities. 
The missions are based on the principles of equity, gender equality, race and ethnicity. They constitute strategies of the inclusion policy that enables the promotion and protection of citizens' rights, for which they are classified into four groups: Robinson I, aimed at the literacy process; Robinson II: aimed at obtaining the 6th grade; Ribas, referring to secondary and professional technical education and the Sucre Mission, linked to access to University Education.

In the particular case of the Sucre Mission, it has been designed as the strategy to break, through Higher Education, the circles of exclusion. It is a relevant task and offers high quality standards. Despite its marked intentionality in strengthening professional training that contributes to endogenous Venezuelan social and economic development, the current historical context has brought with it the desertion of student dropout.

In Latin America the phenomenon of university student dropout has been, in a certain way, attenuated by conceiving spaces that expand access to university education and the permanence of students in universities. The possibility of coming into contact with different ways that are timely and effective is considered

Thus, in the higher education or university systems in Latin America, a process of strong diversification in quality has been registered in recent decades, being considered as a modifying variable the creation of new spaces in which the use of technology is distinguished of information, alternating with the physical spaces of the institutions. However, there are exceptional situations that make it impossible to develop a harmonious teaching process in which face-to-face and distance education converge with the use of technology; such is the case of the historical social context facing the Bolivarian Republic of Venezuela.

\section{Developing}

\section{Livelihoods of the educational process in the Bolivarian Republic of Venezuela}

At the United Nations Conference on Sustainable Development, held in Rio de Janeiro in 2012, the Sustainable Development Goals (SDGs) were created. The purpose was to create a set of global goals related to environmental, political and economic challenges. Subsequently, on September 25, 2015, the UN General Assembly adopted the 2030 Agenda for Sustainable Development.

It is a universal program that focuses its highest aspiration on eradicating poverty, protecting the planet and ensuring that all people enjoy peace, prosperity and justice. 17 objectives are drawn up with 169 goals of an integrated and indivisible nature, which are related to health and well-being, energy, industry, care and protection of the environment, production and consumption, peace...; it's about improving lives, sustainably, for future generations.

However, there is an objective that constitutes a transversal axis in the Agenda, insofar as it sustains all development in society; it's about number 4: quality education. Education is a human right and is recognized as a driving force behind sustainable development based on a culture of peace. Each objective of the 2030 Agenda depends on an education that nurtures all people with the knowledge, habits, skills and values necessary that will allow them to live with dignity, learn to know, to be, to do and to live together, contributing to the development of the society in which they live.

When Sustainable Development Goal 4 speaks of quality education, it is intended to: "Guarantee inclusive and equitable quality education and promote lifelong learning opportunities for all"; UNESCO, as a United Nations agency specialized in education, who directs and coordinates the Education 2030 agenda, with its partners.

Governments have the responsibility to guarantee the right to quality education and, being consistent with the 2030 Agenda, respond to the universal and collective commitment that requires the political will to face educational challenges.

Thus, the Bolivarian Republic of Venezuela, in its Magna Letter, makes explicit the legal bases of the educational process, while recognizing that:

"Education is a human right and a fundamental social duty; it is democratic, free and compulsory. The State will assume it (...) in order to develop the creative potential of each human being and the full exercise of his personality based on active, conscious and supportive participation in the processes of social transformation ingrained with the values of national identity..." (Constitution of the Bolivarian Republic of Venezuela. Art 102. p 24)

In addition, it refers to the fact that:

"Everyone has the right to a comprehensive, quality, permanent education, under equal conditions and opportunities... The State will create and sustain institutions and services sufficiently endowed to ensure 
access, permanence and completion in the educational system. The law will guarantee equal attention to people with special needs or disabilities and to those who are deprived of their freedom or lack basic conditions for their incorporation and permanence in the educational system". (Constitution of the Bolivarian Republic of Venezuela Art 103. p-25)

Venezuelan public policies guarantee access to educational processes, not only with the guarantee of conventional programs, but also with the creation of other non-conventional programs, such as, the Educational Missions. These are oriented towards attending to the educational needs of children, adolescents, youth and adults, academic and professional training; as well as vocational and work orientation and the use of free time.

\section{Municipalization of university education in Venezuela}

What is contained in the Constitution of the Bolivarian Republic of Venezuela is put into practice with the System of Educational Missions. It is taken into consideration that UNESCO, in accordance with target 4.3 of SDG 4, provides: "By 2030, ensure equal access for all men and women to quality technical, vocational and higher education, including university teaching". Consequently, the Sucre Mission is an alternative for access to university education with significant social relevance.

Ibáñez, 1994, understands that university education or higher education has the task of "training competent professionals; individuals who creatively solve, that is, in a novel, efficient and effective way, social problems" (p. 104). It refers to the relationship between society and education that is associated with universities, given in a process in which the capacities and attitudes of individuals are transformed with the double intention of their impact on the transformation of society.

This demands achieving a university institution, in this case the Local Environments for the Development of Social Alternative Studies (ALDEAS), which becomes "the place that offers the opportunity to put in tension all their learning dispositions; that substantially increases your individual responsibility as a manager of knowledge; to reveal the contradictions in society and science, and teach him to identify them. It should be the institution that involves you in the search for solutions to the real problems of society and encourages you to delve into the yet undisclosed mysteries of science and nature through research. (Díaz-Canel, 2011, p.13)

In this sense, the process of municipalization of university education in Venezuela, supported by the Sucre Mission, aims to: "facilitate access and the pursuit of public university education, permanent, comprehensive, free and with equal opportunities for all The high school graduates who demand it, in order to increase the educational level of the Venezuelan population and train citizens committed to the development of the country, through the establishment of new university educational models based on institutional synergy and community participation, based on the imperatives of co-responsible, participatory and protagonist democracy (http://www.misionsucre.gob.ve/, cons June, 2019)

For this, relations are established with the University Institutions that accredit the Training Programs (careers) and, together, monitor their development. Thus, it has its implication in the achievement of the SDG goals conceived in the citizenship for sustainable development, in the attainment of adequate skills for decent work and in equal access to technical / professional and higher education.

Many institutions of the Venezuelan State participate in the Sucre Mission, including ministries, autonomous institutes, higher education institutions, National Armed Forces, as well as a very important number of volunteers who undertake from organizational and logistics tasks, to technical design of programs and the teachers themselves. From the initial training of professionals, individual development is favored and at the same time promoting local, regional and national development with the own impulse of the students' creative potential and the full exercise of their personality in a democratic, participatory and non-democratic society excluding.

With this municipalization policy, an inclusive university education is ensured, open to all equally, assumes attention to diversity and adapts to the needs of students. The integration and inclusion of all social sectors is favored, helping to reduce inequalities in the university VILLAGES, which are organized by municipalities, axes and parishes

In this context, the Sucre Mission constitutes a challenge for its directors and teachers, as it supposes that all students are provided with the essential productive and civic competencies so that they can actively incorporate themselves into society and exercise their essential rights by developing their multiple talents, abilities, skills, attitudes and values; taking into account the differences of origin, resources and possibilities, the socio-economic and cultural situation. In this way, learning to be, learning to live together and learning to transform to contribute to the society that formed them becomes homogeneous when learning to learn and learning to do. 
This challenge becomes greater in exceptional circumstances, taking into account the historical situation that the Bolivarian Republic of Venezuela is going through in the constant siege of the opposition in order to destabilize citizen tranquility for political purposes; all of which has its implication in the consecutiveness of the academic period

The students of the Sucre Mission face this too. The attacks on the electrical system, on the means of transport, currently the pandemic that plagues the world, Covid-19; Among other events, they are ravages that bring with it the interruption of the school period and with it the student desertion in the Sucre Mission. How to mitigate this situation?

This problem finds its solution in information technology, in the use of computers, storage devices, transmission and manipulation of data; that is, in educational technology. We focus on placing the Sucre Mission in distance education

The redesign of spaces for university education in the Venezuelan context of the Sucre Mission. Good practices.

Espadas (2016), recognizes that university spaces can be distinguished by two categories: those demanded by curricular designs, essential for the development of skills and knowledge related to disciplinary fields (classrooms, laboratories) and those that are involved with comprehensive training: sports, cultural and recreational spaces. These spaces have been traditionally created.

For decades, teachers and students have been using educational technology, that is, information and communication resources, processes and tools; more and more elements are being incorporated into the educational environment, creating new spaces for university education

In this sense, the internet and mobile technology have brought about a paradigm shift in the use of technology, as they constitute strength to expand access to education and at the same time to improve the quality of the teaching-educational process. The facility to exchange knowledge, points of view, debate ideas, share scientific results, electronic and interactive books; All of this in a process of searching, analyzing and interpreting the information, gives significant value to technological development seen from the area of education

According to Rama (2014), by recognizing that the virtualization process has transformed the educational dynamics in the classrooms, the face-to-face modality is enriched with the support in the media and the support of a virtual platform that contributes to the consolidation of learning; but not in all cases these means are used to enhance the process in the face-to-face mode. Exceptional situations occur, taking into account the specific historical conditions in which the educational process takes place, becoming the teacher-student communication tool.

It is then when its value becomes more significant, when education finds no brakes and the pursuit of studies becomes a reality that in previous decades we could not have imagined. In this sense, good practices are the experiences of the work in the Sucre Mission, which takes place in the Bolivarian Republic of Venezuela.

UNESCO (2014) defines as good practice: "the initiative, policy or successful action model that proposes an improvement in the academic processes of the students. The socialization of good practices is conceived as a contribution of the university teaching community to the promotion of the quality of education. Correspondingly, the National Open and Distance University (2017) conceives a good university practice as that experience that, once implemented, generates added value to institutional management". UNESCO (2014)

Such is the case of the experience that is shared, the good practices that have their genesis in the development of the Training Programs of the Sucre Mission in exceptional situations, with the purpose of giving continuity to the academic period and thus minimizing desertion or abandonment of the students

\section{Organizational process of the Sucre Mission for the development of Distance Training Programs}

Based on the fact that the quality of university education demands to generate collaborative learning processes, even if it is developed at a distance with the redesign of university spaces; It was started by taking into consideration:

\section{Organizational principles}

- Promote assertive and fluid communication

- Weight training based on learning to learn, to know, to be, to do and to live together

- Make planning with room for flexibility, taking into account the resources available to students

- Guide individual activities that precede collaborative learning

- Take into consideration the diagnosis of the students 
- Stimulate motivation towards the specialty of study

\section{Organizational guidelines for distance education in exceptional conditions}

1. All the criteria provided will be taken into consideration without questioning or attacking the student who issues it, the communication must be assertive. It is a space for everyone to learn.

2. If any student has doubts about a certain aspect or simply wants to go deeper, it will be shared with all the members of the group; In other words, not only teachers will give their criteria, a debate will be created on the subject being analyzed.

3. Study materials and the form to locate others on the internet will be sent; in addition, the Self-Study Guides with the activities to be carried out, which will constitute written evaluations.

4. The Self-Study Guides will also include questions to be discussed in the WhatsApp group of the Training Program.

5. The teacher will prepare a summary with the answers to the written evaluation activities that are oriented, which will be sent to the students after the deadline is closed and before the WhatsApp debate.

6. Once the summary with the pertinent clarifications made by the teacher has been received, they will be able to send any doubts that may arise, which will also be dealt with in the debate by the WhatsApp group

7. They will be able to develop activities individually or in groups of up to 3 students.

8. Once a week, on the day and at the time agreed between teachers and students, the WhatsApp group will promote the exchange of the topic circulated. That same day, at the end of the debate, the materials and the Self-Study Guide for the new topic will be mailed.

9. The qualifications will be circulated, taking into account the written evaluation with the delivery of the Self-Study Guide and the oral evaluation that emerges from the WhatsApp debate. Self-evaluation, hetero-evaluation and co-evaluation may be applied.

10. The WhatSapp group will only be for exchanges, debates, reflections on the topics that are part of the Training Program.

Understanding the WhatsApp group as an alternative, spaces for debates can be created with the use of virtual resources for learning, taking into account the availability of resources of teachers and students.

\section{Methodological suggestions to teachers for the development of the distance teaching process}

The collaborating teachers of the Sucre Mission must ensure that the students develop qualities and skills that guarantee their autonomy and independence and offer them the possibilities to act and deepen the knowledge they acquire, that they learn to study by getting involved with the various sources of information, that they learn to think to overcome the objectives set in each Curricular Unit (subject); the success of the redesign of the university spaces will depend on this. Thus, it is suggested to organize the direction of the teaching process in four fundamental moments: 


\section{Moments for the direction of Methodological suggestions the process}

\begin{tabular}{ll}
\hline $\begin{array}{l}\text { First moment: Assurance } \\
\text { guarantee }\end{array}$ & $\begin{array}{l}\text { Discussion of the organizational guidelines with the details corresponding to } \\
\text { the Training Program. }\end{array}$ \\
& $\begin{array}{l}\text { Guiding base for students: General information on the Curricular Unit: } \\
\text { contents, objectives, schedule, forms of evaluation. }\end{array}$ \\
& $\begin{array}{l}\text { Elaboration of the Curricular Unit Library: Elaborated materials, books, } \\
\text { digital articles, addresses that make it possible to search online. }\end{array}$
\end{tabular}

Second moment: Orientation for the direction of an optimal self-learning

Third moment: Development of the teaching process
Fourth moment: I arrive at conclusions
Preparation and delivery of the Self-Study Guide, specifying: what, how and for what they are going to learn. It is significant:

- Guide the objective, the content, the method, procedures and ways of learning, means, evaluation and time available.

- Explain and exemplify concepts corresponding to the new content.

- Thoroughly clarify the activities and procedures to follow, as well as the bibliography to consult and the guidelines for exchange with the group.

- Check that each student has understood the orientation.

Recapitulation of the objectives, control of the degree of assimilation and the link with previous content: you can establish experience-knowledge relationships in the socialization of the best experiences, in the use of self-learning methods and procedures.

- Control and evaluate the fulfillment of the self-study (orientation of corrective or empowerment measures to learn to learn).

- Stimulate motivations, interests and self-learning needs.

- Evaluate the result of the assimilation of the content and the achievement of the objective, what was learned? Applying self-evaluation, co-evaluation and hetero-evaluation.

- Dialogue that allows the explanation of concepts that, due to their complexity, require it and/or direct the dynamics on some aspect that is complex to process. New learning situations can be considered where students exercise and consolidate the content learned (knowledge system, professional skills, values), summaries, diagrams, concept maps, reports, essays ... can be elaborated.

- Control, evaluation and qualification of learning results.

- Establishing links with what is new to learn.

Integration of the process passed, its results. Check the general objective of the meeting establishing links between the process, the results and the new orientation stage.

- Specify the most common achievements and difficulties in self-learning, the main corrective and empowerment measures to take into account for successive learning, both in content and in the process of learning to learn.

It might seem that the first moment is unrepeatable in the teaching process that takes place at a distance, in this sense it must be taken into consideration that the treatment of the organizational guidelines allows an educational impact that contributes significantly to the comprehensive training of students, future professionals; all of which merits its follow-up in the development of the remaining moments. In the same way, each Self-Study Guide in its individuality, adjusts to the contents, objectives, schedule and forms of evaluation that, in a general way, guide the Curricular Unit and the Library will be increasingly valuable to the extent that it enriches with the contributions of the sciences that pay them and with the contributions of the students themselves 


\section{Conclusions}

Education in its maximum expression constitutes the support of the development of the people. The fact that it is taken into consideration as an integrating objective, a transversal axis that is inserted in the 17 objectives of the 2030 Agenda for Sustainable Development; it supports the true dimension of its importance.

Correspondingly, university education as a lifelong learning process that is based on an integral concept is recognized for its contribution to the general development of society. This finds its significance in the training of professionals with the capacities, abilities and responsibility that allow them to face the contradictions in society and in the sciences and seek solutions that lead to their development in a particular way and that of their country and the world in the general.

In Latin America, the Bolivarian Republic of Venezuela stands out, which, from the Constitution of the Nation, recognizes education as a human right and a fundamental social duty, outlines strategies for the entire population to make use of that right. Thus, an achievement at this educational level is constituted by the Sucre Mission, which is distinguished by municipalization in a territorial dimension that allows access, without restrictions, to university education.

The Sucre Mission arises and develops in traditional university spaces: those demanded by the curricular designs and those that are involved with comprehensive training; However, faced with the confrontation with the sustainability of the teaching process, it recognizes technologies as valuable tools in the redesign of university spaces. It is an organized process that allows minimizing the limitations of the students to sustain their academic pursuit in the face of the economic war, the actions of the government opposition and other events that make, on multiple occasions, the university community face exceptional situations.

Strengthen the experience of redesigning university spaces with the use of communication technology, demand for committed and prepared teachers who open the way and work according to the principle of equal right to education, in an inclusive learning environment that guarantees equal opportunities for professionals on whom the future development of the country will rest in all areas. This merits the follow-up and attention to the methodological suggestions for the development of the teaching process, in its four moments: Guarantee of assurances, Guidance for the direction of an optimal self-learning, Development of the teaching process and Arrival of conclusions; all of which will guarantee a higher quality in the training of professionals in the design of remote university spaces.

\section{References}

Chipia, J., \& Santiago, C. (2020). University education: transition and digital disruption. Critical approach. Journal of the Community and Health Research Group, 5(2), 130-140

Constitución de la República Bolivariana de Venezuela. (1999). Artículos 102,103 y 110 de 1999. Retrieved from https://venezuela.justia.com/federales/constitucion-de-la-republica-bolivariana-de-venezuela/titulo-iii/capitulo-v i/

Espadas, C. A. (2016). Formación de espacios universitarios. Revista Educarnos, (15). Retrieved from https://revistaeducarnos.com/espacios-universitarios-formativos/

Ibáñez, B. C. (1994). Pedagogía y Psicología Interconductual. Revista Mexicana de Análisis de la Conducta, (20), 99-112. Retrieved from http://rmac-mx.org/wp-content/uploads/2013/05/VOL-20-N-1-99-113.pdf

Llopiz, K., Andreu, N., González, R., Alberca, N., Fuster Guillén, D., \& Palacios-Garay, J. (2020). Prácticas educativas inclusivas a través de la educación a distancia. Experiencias en Cuba. Propósitos y representaciones, 8(2), e446. Retrieved from http://revistas.usil.edu.pe/index.php/pyr/article/view/446

Ministerio de Educación Superior, Fundación Misión Sucre. (2005). Fundamentos conceptuales de la Misión Sucre. Retrieved from https://docplayer.es/51447769-Fundamentos-conceptuales-de-la-mision-sucre.html

Miranda, J., Ramírez, C., \& Terán, Y. (2017). Las misiones Robinson, Ribas y Sucre: una experiencia de integración desde la Universidad. Mendive. Revista de Educación, 15(1). Retrieved from http://scielo.sld.cu/scielo.php?pid=S1815-76962017000100001\&script=sci_arttext\&tlng=en

Organización de las Naciones Unidas para la Educación, la Ciencia y la Cultura UNESCO. (2014). Conferencia Mundial sobre el Desarrollo Sostenible. $\quad$ Retrieved from https://unesdoc.unesco.org/ark:/48223/pf0000232888_spa 
Organización de las Naciones Unidas para la Educación, la Ciencia y la Cultura UNESCO. (2020). Liderando el ODS 4 - Educación 2030. Retrieved from https://es.unesco.org/themes/liderar-ods-4-educacion-2030

Organización de las Naciones Unidas, NN. UU. (2012). Conferencia de desarrollo sostenible de Naciones Unidas. Retrieved from https://research.un.org/es/docs/environment/conferences

Organización de las Naciones Unidas, NN. UU. (2015). Agenda para el Desarrollo Sostenible 2030. Una reunión de todos los Estados Miembros de las Naciones Unidas. Retrieved from https://www.un.org/sustainabledevelopment/es/development-agenda/

Organización de las Naciones Unidas, NN. UU. (1948). Declaración Universal de Derechos Humanos. Documento declarativo sobre la universalidad de los derechos humanos. Retrieved from https://www.un.org/es/universal-declaration-human-rights/

Peña, F., \& Otálora, N. (2018). Educación y tecnología: problemas y relaciones. Pedagogía y Saberes, 48, 59-70.

Rama, C. (2014). Virtualización universitaria en América Latina. RUSC. Universities and Knowledge Society Journal, 11(3), 32-41. https://doi.org/10.7238/rusc.v11i3.1729

UNESCO. (2015). ODS4: Educación. Retrieved from https://es.unesco.org/gem-report/node/1346

Zambrano, A., Laurencio, A., \& Milan, M. (2018). La virtualidad como alternativa de formación universitaria. Rev. Didasc @ lia: Didactics and Education, 9(2), 159-179. Retrieved from https://dialnet.unirioja.es/servlet/articulo?codigo=6596592

\section{Copyrights}

Copyright for this article is retained by the author(s), with first publication rights granted to the journal.

This is an open-access article distributed under the terms and conditions of the Creative Commons Attribution license (http://creativecommons.org/licenses/by/4.0/). 